\title{
Containment Analysis of the 9975 Transportation Package with Multiple Barriers
}

by

D. W. Vinson

Westinghouse Savannah River Company

Savannah River Site

Aiken, South Carolina 29808

DOE Contract No. DE-AC09-96SR18500

This paper was prepared in connection with work done under the above contract number with the U. S. Department of Energy. By acceptance of this paper, the publisher and/or recipient acknowledges the U. S. Government's right to retain a nonexclusive, royalty-free license in and to any copyright covering this paper, along with the right to reproduce and to authorize others to reproduce all or part of the copyrighted paper. 


\section{Containment Analysis of the 9975 Transportation Package with Multiple Barriers}

Savannah River Technology Center

Strategic Materials Technology Department

Materials Technology Section

Publication Date: December 1999

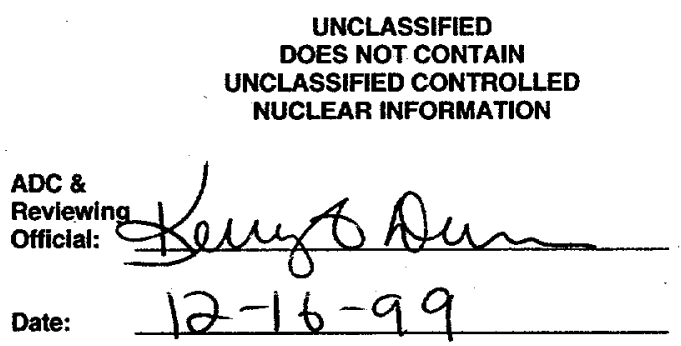

\section{Westinghouse Savannah River Company Savannah River Site Aiken, SC 29808}

This document was prepared in connection with work done under Contract No. DE-AC0996SR 18500 with the U. S. Department of Energy 


\section{DISCLAIMER}

This report was prepared as an account of work sponsored by an agency of the United States Government. Neither the United States Government nor any agency thereof, nor any of their employees, makes any warranty, express or implied, or assumes any legal liability or responsibility for the accuracy, completeness, or usefulness of any information, apparatus, product or process disclosed, or represents that its use would not infringe privately owned rights. Reference herein to any specific commercial product, process or service by trade name, trademark, manufacturer, or otherwise does not necessarily constitute or imply its endorsement, recommendation, or favoring by the United States Government or any agency thereof. The views and opinions of authors expressed herein do not necessarily state or reflect those of the United States Government or any agency thereof.

This report has been reproduced directly from the best available copy.

Available for sale to the public, in paper, from: U.S. Department of Commerce, National Technical Information Service, 5285 Port Royal Road, Springfield, VA 22161, phone: (800) 553-6847 fax: (703) 605-6900

email: orders@ntis.fedworld.gov

online ordering: http://www.ntis.gov/ordering.htm

Available electronically at http://www.doe.gov/bridge

Available for a processing fee to U.S. Department of Energy and its contractors, in paper, from: U.S. Department of Energy, Office of Scientific and Technical Information, P.O. Box 62, Oak Ridge, TN 37831-0062, phone: (865) 576-8401

fax: (865) $576-5728$

email: reports@adonis.osti.gov 


\section{DISCLAIMER}

Portions of this document may be illegible in electronic image products. Images are produced from the best available original document. 
WSRC-TR-99-00476

Page iii of iv

December 1999

DOCUMENT: $\quad$ WSRC-TR-99-00476

TITLE:

CONTAINMENT ANALYSIS OF THE 9975 TRANSPORTATION

PACKAGE WITH MULTIPLE BARRIERS

APPROVALS

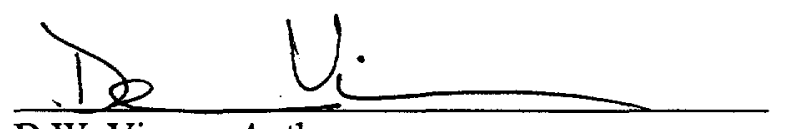

D.W. Vinson, Author SRTC-MATERIALS TECHNOLOGY SECTION

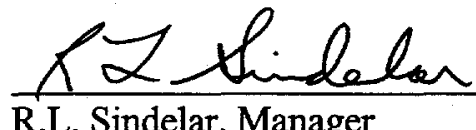

R.L. Sindelar, Manager

Materials Applications and Process Technology SRTC-MATERIALS TECHNOLOGY SECTION

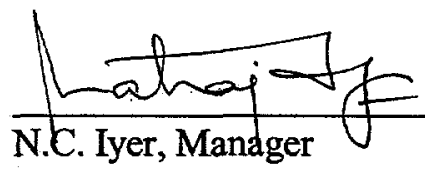

SRTC-MATERIALS TECHNOLOGY SECTION

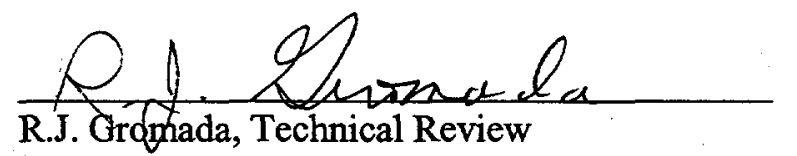

PACKAGING AND TRANSPORTATION GROUP

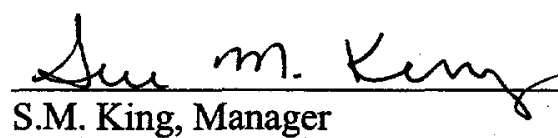

PACKAGING AND TRANSPORTATION GROUP
Date: $12 / 15 / 99$

Date: $12 / 15 / 99$

Date: $12 / 15 / 99$

Date: $12 / 15 / 49$

Date: $121 / 5 / 99$ 


\section{Table of Contents}

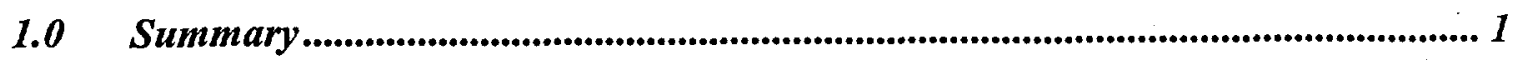

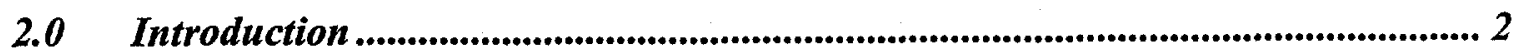

3.0 Containment Analysis of the 9975 for Transporting Plutonium Metal ............... 3

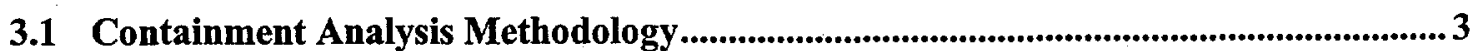

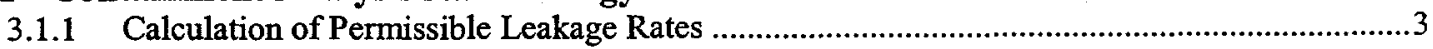

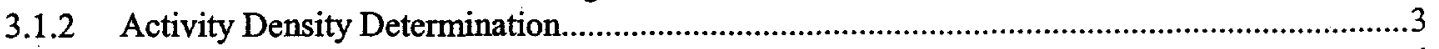

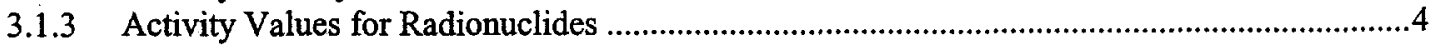

3.1.4 Determination of the Maximum Permissible Leakage Rate .......................................................4

3.1.5 Maximum Permissible Leakage Rate at Standard Conditions......................................................4

3.2 Calculations for Plutonium Metal in the 9975 Package ..............................................5

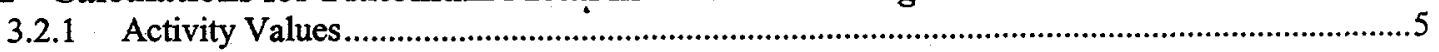

3.2.2 Activity Density Determination.............................................................................................

3.2.3 Maximum Permissible Release Rate and Maximum Permissible Leakage Rate........................8

3.2.4 Permissible Leak Rate at Standard Conditions..........................................................................

3.3 Containment Analysis Results and Discussion ................................................................10

4.0 Analysis of a Multiple Barrier System for Shipping $A$ Hypothetically Breached 9975 Transportation Package Containing Plutonium Metal .............................. 11

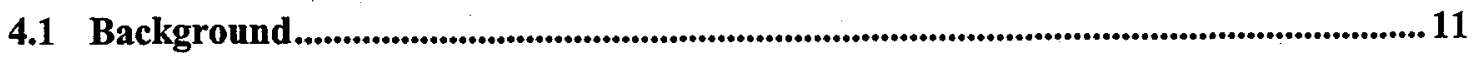

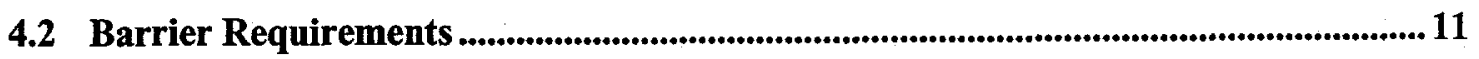

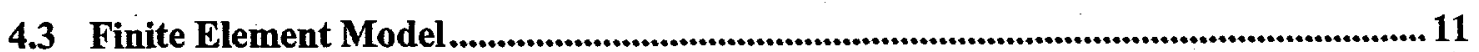

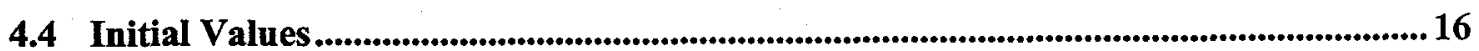

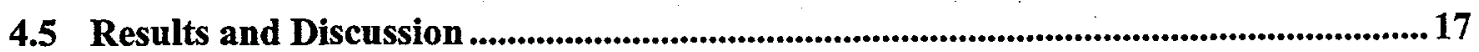

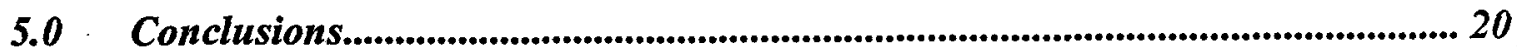




\subsection{SUMMARY}

A containment analysis has been performed for the scenario of non-routine transfer of a damaged 9975 package containing plutonium metal from $\mathrm{K}$-area monitored storage to $\mathrm{F}$-area on the Savannah River Site. A multiple barrier system with each barrier having a defined leakage rate of less than $1 \times 10^{-3} \mathrm{~cm}^{3} / \mathrm{sec}$ of air at Standard Temperature and Pressure was analyzed to determine the number of barriers needed to transport the package under normal transportation conditions to meet transportation requirements for containment. The barrier system was analyzed parametrically to achieve a composite system that met the federal requirements for the maximum permissible release rate given in Title 10 of the Code of Federal Regulations, Part $71 .^{1}$

The multiple barrier system acts to retard the release of radioactivity. That is, a build-up in the radioactivity release rate occurs with time. For example, a system with three barriers (e.g., sealed plastic barrier) with a total free volume of $4,500 \mathrm{~cm}^{3}$ could be transported for a total time of up to approximately 10 days with a release rate within the permissible rate. Additional number of barriers, or volume of the barriers, or both, would extend to this period of time. For example, a system with seven barriers with a total free volume of $4,500 \mathrm{~cm}^{3}$ could be transported for up to 100 days.

Plastic bags are one type of barrier used in movement of radioactive materials and capable of achieving a leak rate of $1 \times 10^{-3} \mathrm{~cm}^{3} / \mathrm{sec}$ of air at STP. ${ }^{2}$ Low-density polyethylene bags can withstand high temperature (up to $180^{\circ} \mathrm{C}$ ); a barrier thickness of 10 mils should be suitable for the barrier system. Additional requirements for barriers are listed in Section 4.2 of this report. Container testing per ANSI N14.5 is required to demonstrate leak rates for the individual barriers of less than $1 \times 10^{-3} \mathrm{~cm}^{3} / \mathrm{sec}$.

\footnotetext{
${ }^{1}$ The containment criterion is that the package has a radioactive release rate less than $\mathrm{A}_{2} \times 10^{-6}$ in one hour where $A_{2}$ is the activity value (in curies) for the transported material.

${ }^{2}$ The soapy bubble leak test described in ANSI N14.5 is one method of demonstrating a leak rate of less than $1 \times 10^{-3} \mathrm{~cm}^{3} / \mathrm{sec}$. If bubbles do not form when the component (sealed barrier) is submerged in soapy water, the leak rate is assumed equal to $1 x 10^{-3} \mathrm{~cm}^{3} / \mathrm{sec}$.
} 


\subsection{INTRODUCTION}

The 9975 transportation package is being used in the $\mathrm{K}$-area monitored storage of plutonium metal. This package is considered leak-tight with respect to transportation of radioactive material (leak rate $<10^{-7} \mathrm{~cm}^{3} / \mathrm{sec}$ air at STP). Scenarios have been proposed whereby the containment barriers of this package have been breached. In this case, the suspect package would need to be transported from KAMS to F-area for disposition. This present report provides a detailed evaluation to demonstrate containment using a multiple-barrier system. Figure 2.1 displays a drawing of the 9975 transportation package taken from WSRC-SA-7, Safety Analysis Report Packages 9965, 9968, 9972-75 Packages (U) (SAR).

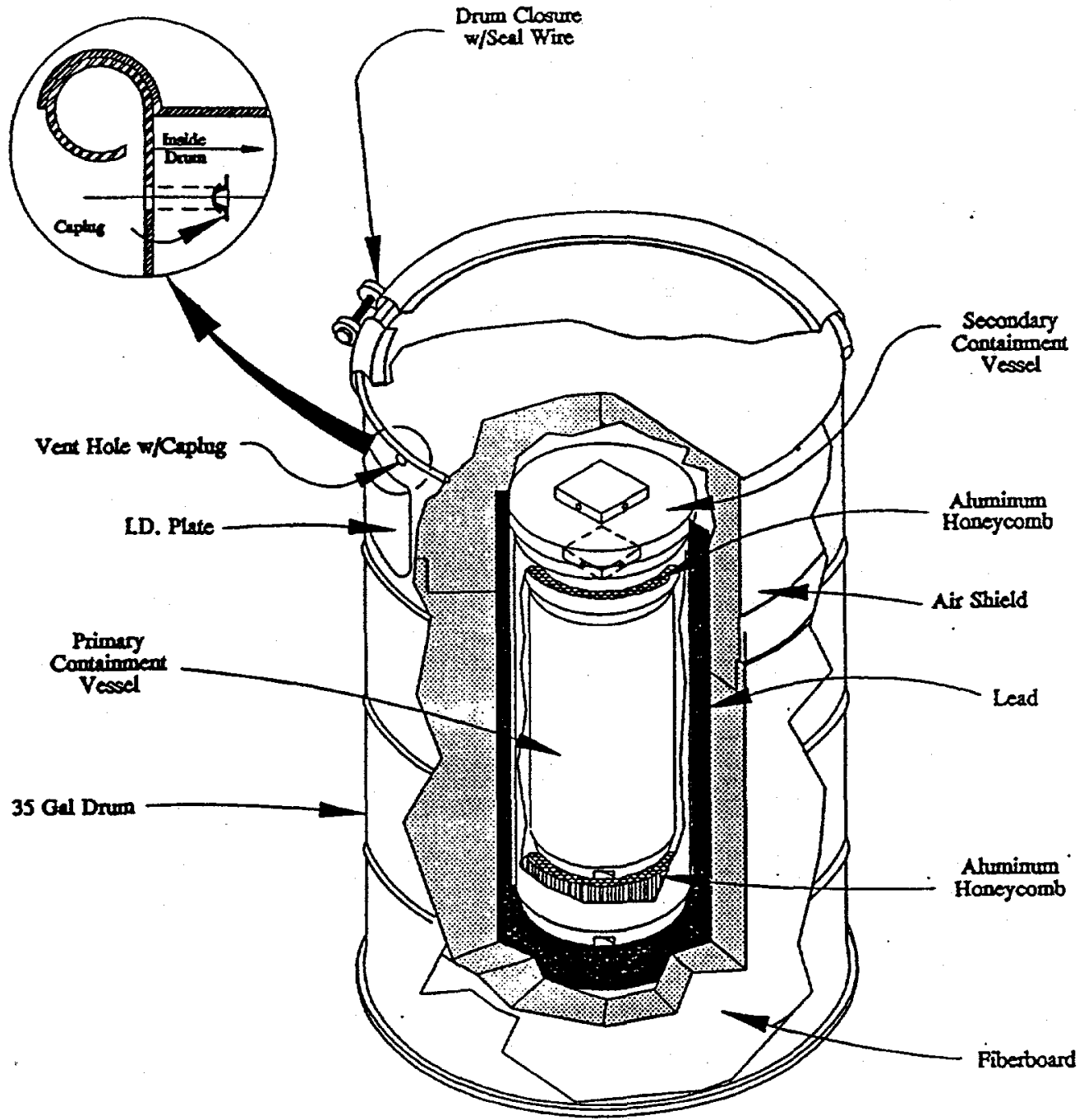

$\ln \pi$

Figure 2.1 Sketch of the 9975 transportation package (taken from the SAR). 


\subsection{CONTAINMENT ANALYSIS OF THE 9975 FOR TRANSPORTING PLUTONIUM METAL}

The methodology (ANSI N14.5) to evaluate containment is summarized in Section 3.1. The determination of the activity source term, $A_{2}$, for the plutonium metal is described in Section 3.2.

\subsection{Containment Analysis Methodology}

The following describes the containment analysis methodology used for the containment evaluation of plutonium metal in the 9975 package.

\subsubsection{Calculation of Permissible Leakage Rates}

The containment criterion for Type $B$ packages requires that a package have a radioactive release rate less than $A_{2} \times 10^{-6}$ in one hour under normal conditions of transport. The parameter $A_{2}$ has units of curies $(\mathrm{C} i)$ and is isotope dependent. $A_{2}$ is calculated from the isotopic curie concentration in the fuel that is determined through the use of maximum allowable isotopic concentrations determined from information in Table 1.10 of the SAR.

The maximum permissible release rate for normal conditions of transport can be expressed as follows:

$$
R_{N}=L_{N} C_{N} \leq A_{2, N} * 2.78 \times 10^{-10} \mathrm{~s}^{-1}
$$

where:

$R_{N} \quad$ is the release rate for normal conditions of transport [ $\left.\mathrm{Ci} / \mathrm{s}\right]$,

$L_{N}$ is the volumetric gas leakage rate $\left[\mathrm{cm}^{3} / \mathrm{s}\right]$ under normal conditions of transport,

$C_{N}$ is the curies per unit volume of the radioactive material, "activity density", that passes through the leak path for conditions of transport $\left[\mathrm{Ci} / \mathrm{cm}^{3}\right]$, and

$A_{2, N}$ is the mixture $A_{2}$ of the radionuclides available for release under conditions of transport $[C i]$.

\subsubsection{Activity Density Determination}

There is only one source of radioactive material that may become airborne during transportation. This sources is fines such that:

$$
C_{\text {total }}=C_{\text {fines }}
$$

where:

$C_{\text {total }}$ is the total releasable activity density inside the containment vessel $\left[\mathrm{Ci} / \mathrm{cm}^{3}\right]$ and

$C_{\text {fines }}$ is the releasable activity density inside the containment vessel due to the release of fines $\left[\mathrm{Ci} / \mathrm{cm}^{3}\right]$.

The releasable activity density inside the containment vessel due to the release of fines is described by Eq. 3 .

$$
C_{\text {fines }}=\frac{M_{\text {oxide }} \times f_{f}}{V_{C}} \mathrm{Ci} / \mathrm{cm}^{3}
$$


where:

$M_{\text {oxide }}$ is the total number of curies of all radionuclides in the plutonium metal form [Ci],

$f_{f} \quad$ is the oxide spallation fraction $\left[f_{f}=0.15\right]$, and

$V_{C}$ is the free volume of the PCV $\left[\mathrm{cm}^{3}\right]$.

\subsubsection{Activity Values for Radionuclides}

The $\mathrm{A}_{2}$ value for the fines is derived from the values provided in Appendix A, Table A-1 of 10CFR71. The $A_{2}$ value for mixtures of isotopes is calculated from:

$$
A_{2}=\left(\sum\left(R_{i} / A_{2_{i}}\right)\right)^{-1} C i
$$

where:

$R_{i} \quad$ is the fraction activity of nuclide $i$ in the mixture and

$A_{2_{i}}$ is the appropriate $A_{2}$ value for nuclide $i$.

\subsubsection{Determination of the Maximum Permissible Leakage Rate}

The maximum permissible leak rate is calculated by using the solutions to Eq. 2 and Eq. 4 and solving for $L_{i}$ in Eq. 1 at normal conditions of transport.

\subsubsection{Maximum Permissible Leakage Rate at Standard Conditions}

The volumetric gas leak rate is modeled as a combination of continuum and molecular flow through a single leak path. The leak path is modeled as a smooth, right-circular cylinder with sharp edges. Based on these assumptions, the equation for gas leaking from the cask takes the following form.

$$
L=L_{c}+L_{m}
$$

where:

$L \quad$ is the volumetric gas flow rate at $\mathrm{P}_{\mathrm{u}}\left[\mathrm{cm}^{3} / \mathrm{sec}\right]$,

$L_{c}$ is the volumetric flow rate due to continuum flow $\left[\mathrm{cm}^{3} / \mathrm{sec}\right]$, and

$L_{m}$ is the volumetric flow rate due to molecular flow $\left[\mathrm{cm}^{3} / \mathrm{sec}\right]$.

The volumetric flow rate, $L_{c}$, for continuum flow is given by

$$
L_{c}=\left[\frac{2.49 \times 10^{6} * D^{4}}{a \mu}\right] *\left(P_{u}-P_{d}\right)=F_{c}\left(P_{u}-P_{d}\right) \mathrm{cm}^{3} / \mathrm{s}
$$

where:

$F_{c}$ is the continuum flow coefficient $\left[\mathrm{cm}^{3} / \mathrm{s}\right]$,

$D$ is the capillary diameter $[\mathrm{cm}]$,

$a$ is the capillary length [ $\mathrm{cm}]$ (typically found in the SAR of a given cask),

$\mu \quad$ is the fluid viscosity [cP] (typically found in CRC Handbook),

$P_{u} \quad$ is the upstream pressure [atm] (typically found in the SAR of a given cask), and

$P_{d} \quad$ is the downstream pressure $[\mathrm{atm}]$. 
The volumetric flow rate, $L_{m}$, for molecular flow is given by

$$
L_{m}=\left[\frac{3.81 \times 10^{3} * D^{3}}{a P_{a}} \times \sqrt{T / M}\right] *\left(P_{u}-P_{d}\right)=F_{m}\left(P_{u}-P_{d}\right) \mathrm{cm}^{3} / \mathrm{s}
$$

where:

$L_{m}$ is the volumetric flow rate due to molecular flow $\left[\mathrm{cm}^{3} / \mathrm{sec}\right]$,

$F_{m}$ is the molecular flow coefficient [ $\left.\mathrm{cm}^{3} / \mathrm{atm} \cdot \mathrm{s}\right]$,

$D$ is the capillary diameter $[\mathrm{cm}]$,

$T$ is the gas temperature $[K]$ (typically found in the SAR of a given cask),

$M$ is the gas molecular weight [ $\mathrm{g} / \mathrm{mole}]$ (typically found in CRC Handbook),

$a$ is the capillary length $[\mathrm{cm}]$ (typically found in the SAR of a given cask),

$P_{u} \quad$ is the upstream pressure [atm], and

$P_{d} \quad$ is the downstream pressure $[\mathrm{atm}]$.

To correlate the maximum permissible leak rate to the leak rate at standard temperature and pressure, Eq. 5 is solved for the capillary diameter (see Eq. 6 and Eq. 7) at the expected environmental conditions. The resulting diameter is then used in Eq. 5 with the temperature equal to $298-K$, the upstream and downstream pressures equal to $1.0 \mathrm{~atm}$ and $0.01 \mathrm{~atm}$. respectively, and the gas molecular weight and viscosity equal to that of dry air at standard temperature and pressure. The resulting leak rate is maximum allowable testing leak rate of the shipping cask.

\subsection{Calculations for Plutonium Metal in the 9975 Package}

The following details the calculations for the containment evaluation of the 9975 package containing plutonium metal. Input for the analysis is provided in the $9975 \mathrm{SAR}$, unless stated otherwise.

\subsubsection{Activity Values}

$\mathrm{A}_{2}$ values are derived from the values provided in Appendix A, Table A-1 of 10CFR71. The $A_{2}$ value for mixtures of isotopes is calculated from Eq. 4. In the specific case of plutonium metal contents permitted in the 9975 package, a bounding composition for containment must be determined. The composition of the plutonium metal allowable in the 9975 package is provided in Table 1.10 of the current SAR as is reproduced in part in Table 3.1

In determining the bounding composition for containment, two compositions were selected. The first composition was derived to provide the lowest value of $A_{2}$, i.e., lowest allowable release rate, while yielding the maximum activity. Maximizing the activity, while ignoring the $A_{2}$ value yielded the second composition. These compositions are provided in Table 3.2 as Case 1 and Case 2, respectively. The activity calculations assume a total mass of $4.4-\mathrm{kg}$.

Using the compositions are provided in Table 3.2, the $A_{2}$ values for the plutonium metal are calculated in Table 3.3 and Table 3.4 , respectively. 
Table 3.1 9975 Package $-{ }^{239}$ Pu Metal

\begin{tabular}{|l|c|}
\hline Isotopes & Max Weight percent \\
\hline${ }^{241} \mathrm{Am}$ & 5.00 \\
\hline${ }^{243} \mathrm{Am}$ & 0.00010 \\
\hline${ }^{244} \mathrm{Cm}$ & 0.00010 \\
\hline${ }^{237} \mathrm{~Np}$ & 2.00 \\
\hline${ }^{236} \mathrm{Pu}$ & 0.000001 \\
\hline${ }^{238} \mathrm{Pu}$ & 0.40 \\
\hline${ }^{239} \mathrm{Pu}$ & 95.00 \\
\hline${ }^{240} \mathrm{Pu}$ & 30.00 \\
\hline${ }^{241} \mathrm{Pu}$ & 2.00 \\
\hline${ }^{242} \mathrm{Pu}$ & 5.00 \\
\hline $\mathrm{U}$ & 1.00 \\
\hline
\end{tabular}

Table 3.2 Plutonium Metal Compositions Considered

\begin{tabular}{|c|c|c|c|c|c|c|}
\hline \multirow[b]{2}{*}{ Isotopes } & \multirow{2}{*}{$\begin{array}{l}\text { Spec. Act. } \\
\text { (Ci/g) }\end{array}$} & \multirow{2}{*}{$\begin{array}{c}\mathbf{A}_{2} \\
\text { (Ci) }\end{array}$} & \multicolumn{2}{|c|}{ Case 1} & \multicolumn{2}{|c|}{ Case 2} \\
\hline & & & Wt \% & $\begin{array}{l}\text { Activity } \\
\text { (Ci) }\end{array}$ & Wt \% & $\begin{array}{l}\text { Activity } \\
\text { (Ci) }\end{array}$ \\
\hline${ }^{241} \mathrm{Am}$ & 3.4 & 0.00541 & 5.00 & 748.0 & - & - \\
\hline${ }^{243} \mathrm{Am}$ & 0.2 & 0.00541 & 0.00010 & 0.00088 & - & - \\
\hline${ }^{236} \mathrm{Pu}$ & 534.0 & 0.0189 & & & 0.000001 & 0.0235 \\
\hline${ }^{238} \mathrm{Pu}$ & 17.0 & 0.00541 & 0.40 & 299.2 & 0.4 & 299.2 \\
\hline${ }^{239} \mathrm{Pu}$ & 0.062 & 0.00541 & 64.6 & 176.2 & 67.6 & 184.4 \\
\hline${ }^{240} \mathrm{Pu}$ & 0.23 & 0.00541 & 30.0 & 303.6 & 30 & 303.6 \\
\hline${ }^{241} \mathrm{Pu}$ & 100.0 & 0.270 & - & - & 2 & 8800 \\
\hline \multicolumn{3}{|c|}{ Total Activity (Ci) } & & 1527 & & 9587 \\
\hline
\end{tabular}

Table 3.3 Mixture $A_{2}$ Determination-Case 1

\begin{tabular}{|c|c|c|c|c|}
\hline Isotope & $\begin{array}{c}\mathbf{A}_{2} \text {-Value } \\
\text { (Ci) } \\
\mathbf{A}_{2, \mathbf{i}} \\
\end{array}$ & $\begin{array}{c}\text { Activity } \\
\text { (Ci) } \\
\mathbf{A}_{\mathbf{i}} \\
\end{array}$ & $\begin{array}{c}\text { Fraction } \\
\text { (Fr) } \\
\mathbf{R}_{\mathrm{i}}=\mathbf{A}_{\mathrm{i}} / \Sigma \mathbf{A}_{\mathrm{i}}\end{array}$ & $\begin{array}{l}\mathbf{F r} / \mathbf{A}_{2} \\
(\mathbf{1} / \mathbf{C i}) \\
\mathbf{R}_{\mathbf{i}} / \mathbf{A}_{2, \mathbf{i}} \\
\end{array}$ \\
\hline${ }^{241} \mathrm{Am}$ & $5.41 \mathrm{E}-03$ & $7.48 \mathrm{E}+02$ & $4.90 \mathrm{E}-01$ & $9.05 \mathrm{E}+01$ \\
\hline${ }^{243} \mathrm{Am}$ & $5.41 \mathrm{E}-03$ & $8.80 \mathrm{E}-04$ & $5.76 \mathrm{E}-07$ & $1.07 \mathrm{E}-04$ \\
\hline${ }^{238} \mathrm{Pu}$ & $5.41 \mathrm{E}-03$ & $2.99 \mathrm{E}+02$ & $1.96 \mathrm{E}-01$ & $3.62 \mathrm{E}+01$ \\
\hline${ }^{239} \mathrm{Pu}$ & $5.41 \mathrm{E}-03$ & $1.76 \mathrm{E}+02$ & $1.15 \mathrm{E}-01$ & $2.13 E+01$ \\
\hline${ }^{240} \mathrm{Pu}$ & $5.41 \mathrm{E}-03$ & $3.04 \mathrm{E}+02$ & $1.99 \mathrm{E}-01$ & $3.67 \mathrm{E}+01$ \\
\hline \multirow[t]{2}{*}{ Sum Totals } & $\Sigma \mathbf{A}_{\mathbf{i}}=$ & $1.53 \mathrm{E}+03$ & $\Sigma R_{1} / A_{2 i}=$ & $1.85 \mathrm{E}+02$ \\
\hline & & & $\mathbf{A}_{2}=$ & $5.41 \mathrm{E}-03$ \\
\hline
\end{tabular}


Table 3.4 Mixture A2 Determination - Case 2

\begin{tabular}{|c|c|c|c|c|}
\hline Isotope & $\begin{array}{c}\mathbf{A}_{2}-\text { Value } \\
\text { (Ci) } \\
\mathbf{A}_{2, \mathbf{i}} \\
\end{array}$ & $\begin{array}{c}\text { Activity } \\
\text { (Ci) } \\
\mathbf{A}_{\mathbf{i}} \\
\end{array}$ & $\begin{array}{c}\text { Fraction } \\
(\mathbf{F r}) \\
\mathbf{R}_{\mathbf{i}}=\mathbf{A}_{\mathbf{i}} / \mathbf{\Sigma} \mathbf{A}_{\mathbf{i}} \\
\end{array}$ & $\begin{array}{l}\mathrm{Fr} / \mathbf{A}_{2} \\
(\mathbf{1} / \mathrm{Ci}) \\
\mathbf{R}_{\mathbf{i}} / \mathbf{A}_{2, \mathbf{i}} \\
\end{array}$ \\
\hline${ }^{236} \mathrm{Pu}$ & $1.89 \mathrm{E}-02$ & $2.35 \mathrm{E}-02$ & $2.45 \mathrm{E}-06$ & $1.30 \mathrm{E}-04$ \\
\hline${ }^{238} \mathrm{Pu}$ & $5.41 \mathrm{E}-03$ & $2.99 \mathrm{E}+02$ & $3.12 \mathrm{E}-02$ & $5.77 \mathrm{E}+00$ \\
\hline${ }^{239} \mathrm{Pu}$ & $5.41 \mathrm{E}-03$ & $1.84 \mathrm{E}+02$ & $1.92 \mathrm{E}-02$ & $3.56 \mathrm{E}+00$ \\
\hline${ }^{240} \mathrm{Pu}$ & $5.41 \mathrm{E}-03$ & $3.04 \mathrm{E}+02$ & $3.17 \mathrm{E}-02$ & $5.85 \mathrm{E}+00$ \\
\hline${ }^{241} \mathrm{Pu}$ & $2.70 \mathrm{E}-01$ & $8.80 \mathrm{E}+03$ & $9.18 \mathrm{E}-01$ & $3.40 \mathrm{E}+00$ \\
\hline \multicolumn{2}{|l|}{ Sum Totals } & $9.59 \mathrm{E}+03$ & $\Sigma R_{i} / A_{2 i}=$ & $1.86 \mathrm{E}+01$ \\
\hline & & & $\mathbf{A}_{2}=$ & 5.38E-02 \\
\hline
\end{tabular}

\subsubsection{Activity Density Determination}

The releasable activity density inside the containment vessel due to the release of fines is described by equation Eq. 3. Appendix 4.1 of the SAR provides a calculation for the amount of oxide that can form on the plutonium metal yielding the maximum activity. This methodology is followed to determine the composition and mass of oxide for this containment evaluation. It is assumed that the number of moles of $\mathrm{O}_{2}$ that are available to react with the metal is equal to that calculated in the referenced appendix or 0.03122 moles $\mathrm{O}_{2}$. The following two sections provide calculations for the content of the oxides formed on the plutonium metal assuming the compositions detailed in Table 3.2. It is recognized that unless the barrier system for containment is installed immediately, additional oxidation of the plutonium metal may occur. Therefore, this limit to $\mathrm{O}_{2}$ to produce $\mathrm{MO}_{2}$ may not be conservative.

Since the mole ration of $\mathrm{O}_{2}$ to $\mathrm{MO}_{2}$ (metal oxide) is one, there are 0.03122 moles of $\mathrm{MO}_{2}$ formed by reaction with the oxygen in air and in the water vapor present when the metal is packaged. The mole ration of $\mathrm{M}$ to $\mathrm{MO}_{2}$ is also one, therefore, 0.03122 moles of $\mathrm{M}$ are in the oxide form due to this reaction. The mass of metal $(\mathrm{M})$ formed by the metal oxidation requires the molecular weight of the metals being oxidized. The molecular weight of the metal is determined by first determining the number of moles of each metal constituent of the oxide. These values are used to determine the mole fraction of each isotope, which is then multiplied by the isotopes' molecular weight. The results are summed to provide the molecular weight of the metals. This molecular weight is then multiplied by the number of moles of metal that is reacted (i.e., the number of moles of $\mathrm{O}_{2}$ that reacts) to yield the mass of metal in the oxide. These calculations are provided in Table 3.5 and Table 3.6, for Case 1 and Case 2, respectively.

The amount of radioactive material that may be aspirated is then given by Eq. 3 as follows:

\section{Case 1}

$$
C_{\text {fines }}=\frac{2.59 \times 0.15}{3389}=1.15 \times 10^{-4} \mathrm{Ci} / \mathrm{cm}^{3}
$$




\section{Case 2}

$$
C_{\text {fines }}=\frac{16.3 \times 0.15}{3389}=7.21 \times 10^{-4} \mathrm{Ci} / \mathrm{cm}^{3}
$$

In the above calculations, the PCV free volume is assumed equal to that used in the calculations in Appendix 4.1 of the SAR $\left(3389 \mathrm{~cm}^{3}\right)$.

Table 3.5 Metal Oxidation Calculations - Case 1

\begin{tabular}{|l|c|c|c|c|c|c|}
\hline Isotope & $\begin{array}{c}\text { Molecular } \\
\text { Weight }\end{array}$ & \# Moles & $\begin{array}{c}\text { Mole } \\
\text { Fraction }\end{array}$ & $\begin{array}{c}\text { Fractional } \\
\text { Molecular } \\
\text { Weight }\end{array}$ & $\begin{array}{c}\text { Grams in } \\
\text { Oxide }\end{array}$ & $\begin{array}{c}\text { Curies in } \\
\text { Oxide }\end{array}$ \\
\hline${ }^{241} \mathrm{Am}$ & 241.057 & $9.13 \mathrm{E}-01$ & $4.97 \mathrm{E}-02$ & $1.20 \mathrm{E}+01$ & $3.74 \mathrm{E}-01$ & $1.27 \mathrm{E}+00$ \\
\hline${ }^{243} \mathrm{Am}$ & 243.061 & $1.81 \mathrm{E}-05$ & $9.85 \mathrm{E}-07$ & $2.39 \mathrm{E}-04$ & $7.48 \mathrm{E}-06$ & $1.50 \mathrm{E}-06$ \\
\hline${ }^{236} \mathrm{Pu}$ & 236.046 & $7.39 \mathrm{E}-02$ & $4.02 \mathrm{E}-03$ & $9.58 \mathrm{E}-01$ & $2.99 \mathrm{E}-02$ & $5.08 \mathrm{E}-01$ \\
\hline${ }^{238} \mathrm{Pu}$ & 238.05 & $1.19 \mathrm{E}+01$ & $6.47 \mathrm{E}-01$ & $1.55 \mathrm{E}+02$ & $4.83 \mathrm{E}+00$ & $2.99 \mathrm{E}-01$ \\
\hline${ }^{239} \mathrm{Pu}$ & 239.052 & $5.50 \mathrm{E}+00$ & $2.99 \mathrm{E}-01$ & $7.18 \mathrm{E}+01$ & $2.24 \mathrm{E}+00$ & $5.16 \mathrm{E}-01$ \\
\hline Totals & \multicolumn{7}{|c|}{$\mathbf{2 3 9 . 4 5}$} & $\mathbf{7 . 4 8}$ & $\mathbf{2 . 5 9}$ \\
\hline \multicolumn{7}{|c|}{ Total grams of $\mathrm{M}=0.03122$ moles $\left(\frac{239.45 \mathrm{~g}}{\text { mole }}\right)=7.48 \mathrm{~g}$} \\
\hline
\end{tabular}

Table 3.6 Metal Oxidation Calculations - Case 2

\begin{tabular}{|c|c|c|c|c|c|c|}
\hline Isotope & $\begin{array}{c}\text { Molecular } \\
\text { Weight }\end{array}$ & \# Moles & $\begin{array}{c}\text { Mole } \\
\text { Fraction }\end{array}$ & $\begin{array}{c}\text { Fractional } \\
\text { Molecular } \\
\text { Weight }\end{array}$ & $\begin{array}{l}\text { Grams in } \\
\text { Oxide }\end{array}$ & $\begin{array}{c}\text { Curies in } \\
\text { Oxide }\end{array}$ \\
\hline${ }^{236} \mathrm{Pu}$ & 236.046 & $1.86 \mathrm{E}-07$ & $1.01 \mathrm{E}-08$ & $2.39 \mathrm{E}-06$ & $7.47 \mathrm{E}-08$ & $3.99 \mathrm{E}-05$ \\
\hline${ }^{238} \mathrm{Pu}$ & 238.05 & $7.39 \mathrm{E}-02$ & $4.02 \mathrm{E}-03$ & $9.58 \mathrm{E}-01$ & $2.99 \mathrm{E}-02$ & $5.08 \mathrm{E}-01$ \\
\hline${ }^{239} \mathrm{Pu}$ & 239.052 & $1.24 \mathrm{E}+01$ & $6.77 \mathrm{E}-01$ & $1.62 \mathrm{E}+02$ & $5.05 \mathrm{E}+00$ & 3.13E-01 \\
\hline${ }^{240} \mathrm{Pu}$ & 240.054 & $5.50 \mathrm{E}+00$ & $2.99 \mathrm{E}-01$ & $7.18 \mathrm{E}+01$ & $2.24 \mathrm{E}+00$ & $5.16 \mathrm{E}-01$ \\
\hline${ }^{241} \mathrm{Pu}$ & 241.057 & $3.65 \mathrm{E}-01$ & $1.99 \mathrm{E}-02$ & $4.79 \mathrm{E}+00$ & $1.49 \mathrm{E}-01$ & $1.49 \mathrm{E}+01$ \\
\hline \multicolumn{2}{|l|}{ Totals } & $1.84 \mathrm{E}+01$ & \multicolumn{2}{|r|}{239.39} & 7.47 & 16.3 \\
\hline \multicolumn{3}{|c|}{ Total grams of $\mathrm{M}=0.03122$ moles } & $s\left(\frac{239.67 g}{m o l e}\right.$ & \multicolumn{2}{|l|}{$=7.47 \mathrm{~g}$} & \\
\hline
\end{tabular}

\subsubsection{Maximum Permissible Release Rate and Maximum Permissible Leakage Rate}

The maximum permissible release rate for normal conditions of transport are determined below using Eq. 1. 


\section{Case 1}

$$
\begin{aligned}
& R_{N}=L_{N} C_{N} \leq A_{2, N} * 2.78 \times 10^{-10} \mathrm{~s}^{-1} \\
& L_{N} \leq \frac{5.41 \times 10^{-3} * 2.78 \times 10^{-10}}{1.15 \times 10^{-4}}=1.31 \times 10^{-8} \mathrm{~cm}^{3} / \mathrm{s}
\end{aligned}
$$

\section{Case 2}

$$
\begin{aligned}
& R_{N}=L_{N} C_{N} \leq A_{2, N} * 2.78 \times 10^{-10} \mathrm{~s}^{-1} \\
& L_{N} \leq \frac{5.38 \times 10^{-2} * 2.78 \times 10^{-10}}{7.21 \times 10^{-4}}=2.07 \times 10^{-8} \mathrm{~cm}^{3} / \mathrm{s}
\end{aligned}
$$

\subsubsection{Permissible Leak Rate at Standard Conditions}

Determination of the permissible leak rate at standard conditions utilizes Eq. 5 - Eq. 7.

$$
\begin{aligned}
& L=L_{c}+L_{m} \\
& L_{c}=\left[\frac{2.49 \times 10^{6} * D^{4}}{a \mu}\right] *\left(P_{u}-P_{d}\right)=F_{c}\left(P_{u}-P_{d}\right) \mathrm{cm}^{3} / \mathrm{s} \\
& L_{m}=\left[\frac{3.81 \times 10^{3} * D^{3}}{a P_{a}} \times \sqrt{T / M}\right] *\left(P_{u}-P_{d}\right)=F_{m}\left(P_{u}-P_{d}\right) \mathrm{cm}^{3} / \mathrm{s} \\
& L=\left[\frac{2.49 \times 10^{6} * D^{4}}{a \mu}+\frac{3.81 \times 10^{3} * D^{3}}{a P_{a}} \times \sqrt{T / M}\right] *\left(P_{u}-P_{d}\right) \\
& L=\left[\frac{2.49 \times 10^{6} * D^{4}}{0.381 \times 0.0232}+\frac{3.81 \times 10^{3} * D^{3}}{0.381 \times 1.3} \times \sqrt{429.1 / 29}\right] *(1.6-1) \\
& L=\left[2.82 \times 10^{8} * D^{4}+2.96 \times 10^{4} * D^{3}\right] *(0.6) \\
& L=1.69 \times 10^{8} * D^{4}+1.78 \times 10^{4} * D^{3} \\
& L
\end{aligned}
$$

\section{Case 1}

Substituting $L=1.31 \times 10^{-8} \mathrm{~cm}^{3} / \mathrm{s}$ and solving for $D$ yields a capillary diameter of $7.44 \times 10^{-5} \mathrm{~cm}$.

\section{Case 2}

Substituting $L=2.07 \times 10^{-8} \mathrm{~cm}^{3} / \mathrm{s}$ and solving for $D$ yields a capillary diameter of $8.51 \times 10^{-5} \mathrm{~cm}$. 
To correlate the maximum permissible leak rates calculated in Section 3.2.3 to the leak rate at standard temperature and pressure, the calculated capillary diameter is substituted into Eq. 5Eq. 7.

$$
\begin{aligned}
& L_{R}=\left[\frac{2.49 \times 10^{6} * D^{4}}{a \mu}+\frac{3.81 \times 10^{3} * D^{3}}{a P_{a}} \times \sqrt{T / M}\right] *\left(P_{u}-P_{d}\right) \\
& L_{R}=\left[\frac{2.49 \times 10^{6} * D^{4}}{0.381 \times 0.0185}+\frac{3.81 \times 10^{3} * D^{3}}{0.381 \times 0.505} \times \sqrt{298 / 29}\right] *(1-0.01) \\
& L_{R}=\left[3.53 \times 10^{8} * D^{4}+6.35 \times 10^{4} * D^{3}\right] *(0.99) \\
& L_{R}=3.50 \times 10^{8} * D^{4}+6.28 \times 10^{4} * D^{3}
\end{aligned}
$$

Case 1

Substituting $D=7.44 \times 10^{-5} \mathrm{~cm}$, a reference standard leak rate of $L_{R}=3.66 \times 10^{-8} \mathrm{~cm}^{3} / \mathrm{s}$ is calculated.

\section{Case 2}

Substituting $D=8.51 \times 10^{-5} \mathrm{~cm}$, a reference standard leak rate of $L_{R}=5.71 \times 10^{-8} \mathrm{~cm}^{3} / \mathrm{s}$ is calculated.

\subsection{Containment Analysis Results and Discussion}

A traditional containment system must be leak-tight (i.e., leak rate $\leq 1 \times 10^{-7} \mathrm{~cm}^{3} / \mathrm{s}$ ) to transport the plutonium metal. However, the next section will demonstrate the application of a multiple barrier containment system for transport of a hypothetically breached 9975 transportation package for a shipment of short duration. Multiple barrier systems have been recently evaluated. This present work extends that of Towell, et al. ${ }^{3}$, and shows that a barrier system of several barriers would provide sufficient containment of the suspect 9975 package.

\footnotetext{
${ }^{3}$ Towell, R.H., Kapoor, A, Moses, S.B., and Oras, J.J., "Method of Estimating the Leakage of Multiple Barriers in a Radioactive Materials Shipping Package," Transportation, Storage, and Disposal of Radioactive Materials, PVP-Vol. 348, ASME (1997).
} 


\subsection{ANALYSIS OF A MULTIPLE BARRIER SYSTEM FOR SHIPPING A HYPOTHETICALLY BREACHED 9975 TRANSPORTATION PACKAGE CONTAINING PLUTONIUM METAL}

\subsection{Background}

Recent work ${ }^{4}$ has been completed concerning the performance of multiple leaky barriers, i.e., barriers with individual leak rates higher than the maximum allowable leak rate for the contents being shipped, in containing radioactive materials in a shipping package. The analysis employs finite element modeling of multiple watertight barriers to demonstrate that the nested barriers will provide containment of the radioactive contents for up to several weeks without exceeding the regulatory limit of $1 \times 10^{-6} \mathrm{~A} / \mathrm{hr}$ under normal conditions of transport for type B packages. This section will present the application of the finite element model with some minor modifications to the 9975 package in the event that a forklift tine damages the package. The barriers are sealed materials added to the outside of the 9975 package. That is, credit is not taken for components of the damaged 9975 package.

\subsection{Barrier Requirements}

This analysis is limited to normal conditions of transport. The multiple leaky barriers are required to maintain a leak rate less than $1 x 10^{-3} \mathrm{std} \cdot \mathrm{cm}^{3} / \mathrm{s}$ by ANSI N14.5. Engineering controls must be implemented that will provide relief from structural and thermal requirements. However, this analysis is not applicable in the situation where atmospheric pressure variations generate pressures on the barriers that exceed the barriers' capability to provide $1 \times 10^{-3} \mathrm{std} \cdot \mathrm{cm}^{3} / \mathrm{s}$ containment. Furthermore, detailed consideration of minor pressure changes due to ambient temperature variations is strongly suggested for long shipping times (greater than $\sim 100$ days) due to model sensitivity to ambient pressure.

\subsection{Finite Element Model}

Towell, et al. developed a model for describing the behavior of multiple leaky barriers with respect to the transportation requirements of 10CFR71. The model consists of seven simultaneous linear differential equations for each barrier, four equations for the mass balance of the carrier gas and three equations for the mass balance of radioactive aerosol particles. This model has been modified in the present analysis to allow for pressure and radioactive material reduction in the inner barrier by flow into the next barrier. Also, the model has been expanded to include up to ten nested barriers.

Consistent with the Towell modeling work, the current analysis assumes that the carrier gas behaves as a perfect gas and that the leak hole diameter is constant and is related to the value measured in the leak test of the barrier. Following are the finite element equations solved for the 9975 package. This matrix is set up for ten barriers. In the interest of conserving space, the finite element equations for the second through the ninth barrier are omitted from the matrix. However, they may be readily derived from Eq. 8 - Eq. 14 .

\footnotetext{
${ }^{4}$ Towell, R.H., Kapoor, A, Moses, S.B., and Oras, J.J., "Method of Estimating the Leakage of Multiple Barriers in a Radioactive Materials Shipping Package," Transportation, Storage, and Disposal of Radioactive Materials, PVP-Vol. 348, ASME (1997).
} 


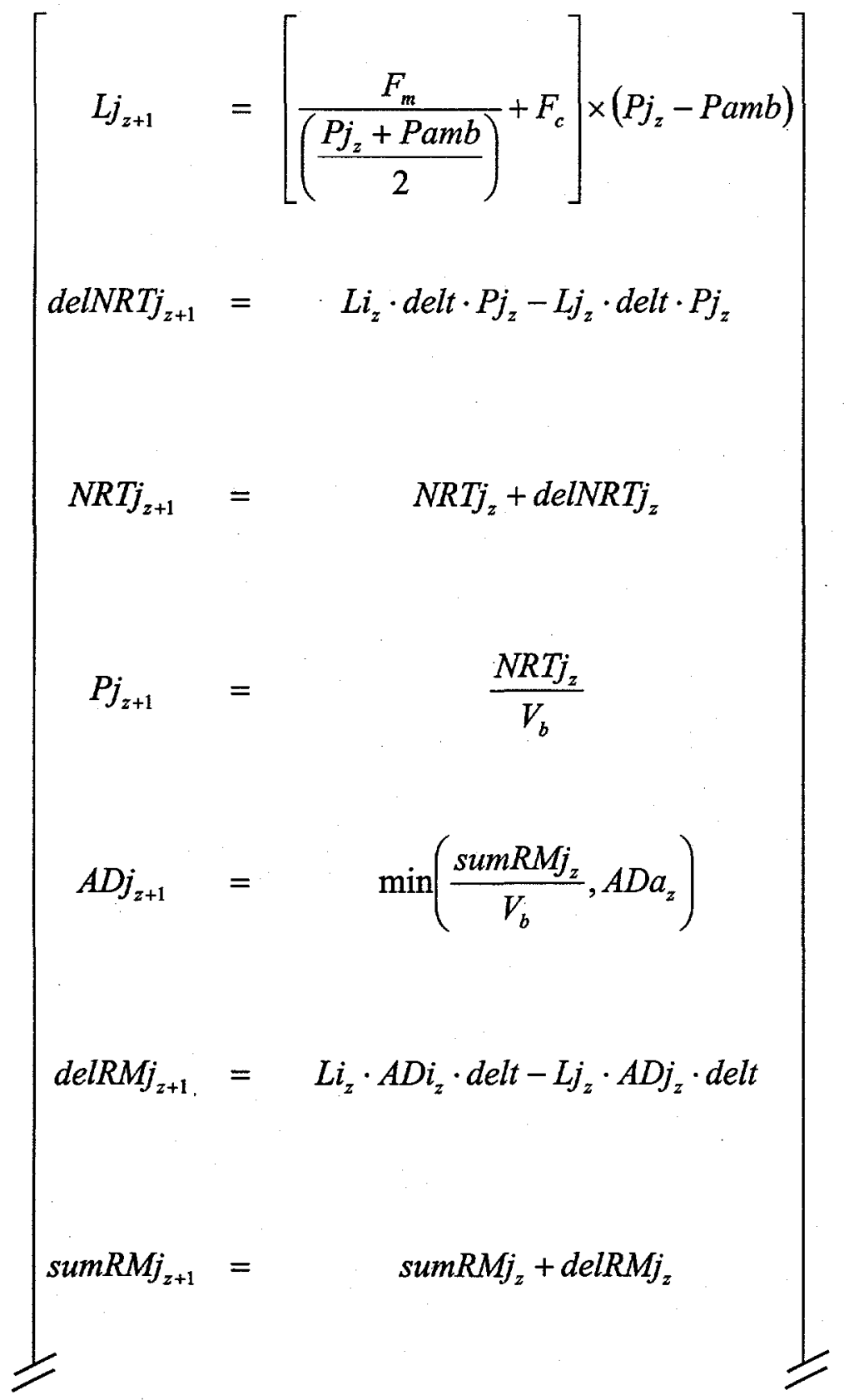

Note: If the new calculated pressure for a given barrier is less than the new calculated pressure for the next outer barrier, the new pressure for that given barrier is assigned a value equal to the average of the pressure of the given barrier in the previous time step and the next outer barrier in the current time step (i.e., $P j_{z+1}=\left(P j_{z}+P_{a m b}\right) / 2$ ). 


$$
\left\{\begin{array}{ccc}
L a_{z+1} & =\left[\frac{F_{m}}{\left(\frac{P a_{z}+P b_{z}}{2}\right)}+F_{c}\right] \times\left(P a_{z}-P b_{z}\right)
\end{array}\right]
$$

Note: If the new calculated pressure for a given barrier is less than the new calculated pressure for the next outer barrier, the new pressure for that given barrier is assigned a value equal to the average of the pressure of the given barrier in the previous time step and the next outer barrier in the current time step (i.e., $P a_{z+1}=\left(P a_{z}+P b_{z+1}\right) / 2$ ). 
In addition to the calculation for the matrix above, the following set of calculations are carried out to determine the release rate of the multiple barrier system in $A_{2} /$ hour.

$$
\begin{aligned}
& R L a_{z}=\left(A D a_{z} \cdot L a_{z} \cdot 3600 \cdot A_{2} \text { mass }\right) \quad A_{2} / \text { hour } \\
& R L f_{z}=\left(A D f_{z} \cdot L f_{z} \cdot 3600 \cdot A_{2} \text { mass }\right) \quad A_{2} / \text { hour }
\end{aligned}
$$

The release rate of the multiple barrier system is characterized by the release rate of the outer barrier of the containment system (i.e., $R L f_{z}$ ). This value must be less than $1 \times 10^{-6} \mathrm{~A} /$ hour in order to comply with the containment requirements of $10 \mathrm{CFR} 71$.

The following paragraphs describe the variables used in this model and the initial conditions for solving the finite element matrix.

The containers are identified by letters, " $a$ " for the innermost, assigned sequentially through the outermost, " $j$ " in the current case, and the ambient is identified by the symbol "amb". The solution begins with the calculation of $F_{c}$ and $F_{m}$. These variables are determined by first using Eq. 5 - Eq. 7 at standard conditions to determine the aperture diameter as follows. The diameter of the leak path is determined by assuming a leak rate of each barrier equal to $1 \times 10^{-3} \mathrm{~cm}^{3} / \mathrm{s}$ and solving for $D$.

$$
\begin{aligned}
& L=L_{c}+L_{m} \\
& L_{c}=\left[\frac{2.49 \times 10^{6} * D^{4}}{a \mu}\right] *\left(P_{u}-P_{d}\right)=F_{c}\left(P_{u}-P_{d}\right) \mathrm{cm}^{3} / \mathrm{s} \\
& L_{m}=\left[\frac{3.81 \times 10^{3} * D^{3}}{a P_{a}} \times \sqrt{T / M}\right] *\left(P_{u}-P_{d}\right)=F_{m}\left(P_{u}-P_{d}\right) \mathrm{cm}^{3} / \mathrm{s} \\
& L=\left[\frac{2.49 \times 10^{6} * D^{4}}{a \mu}+\frac{3.81 \times 10^{3} * D^{3}}{a P_{a}} \times \sqrt{T / M}\right] *\left(P_{u}-P_{d}\right) \\
& 1 \times 10^{-3}=\left[\frac{2.49 \times 10^{6} * D^{4}}{0.381 \times 0.0185}+\frac{3.81 \times 10^{3} * D^{3}}{0.381 \times 0.505} \times \sqrt{298 / 29}\right] *(1-0.01) \\
& 1 \times 10^{-3}=3.50 \times 10^{8} * D^{4}+6.28 \times 10^{4} * D^{3}
\end{aligned}
$$

The calculated aperture diameter is $1.26 \times 10^{-3} \mathrm{~cm}$. This diameter is used in the equations for $F_{c}$ and $F_{m}$ where the average pressure is factored out. The equations for the constants, $F_{c}$ and $F_{m}$ have the following form: 


$$
\begin{aligned}
& F_{c}=\frac{2.49 \times 10^{6} * D^{4}}{a \mu}=\frac{2.49 \times 10^{6} *\left(1.26 \times 10^{-3}\right)^{4}}{0.381 \times 0.0232}=7.10 \times 10^{-4} \\
& F_{m}=\frac{3.81 \times 10^{3} * D^{3}}{a} \times \sqrt{T / M}=\frac{3.81 \times 10^{3} *\left(1.26 \times 10^{-3}\right)^{3}}{0.381} \times \sqrt{429.1 / 29}=7.69 \times 10^{-5}
\end{aligned}
$$

These are the variables defined in equations B3 and B4 of ANSI N14.5 with the average pressure across a barrier factored out of equation B4 (for $F_{m}$ ) so that the leakage rates of the independent

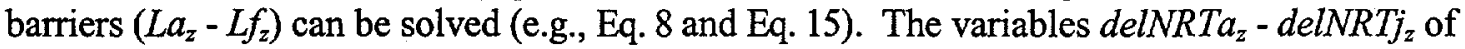
the finite element matrix (e.g., Eq. 9 and Eq. 16) are from the perfect gas law, $N R T=P V$, and are set equal to the product of the carrier gas leakage rate into the barrier, the finite time element, and the pressure within the barrier minus the product of the carrier gas leakage rate out of the barrier, the finite time element, and the pressure within the barrier. The variables $N R T a_{z}-N R T j_{z}$ of the finite element matrix (e.g., Eq. 10 and Eq. 17) accumulate the pressure-volume product of all the gas inside the given barrier. The variables $P a_{z}-P j_{z}$ of the finite element matrix (e.g., Eq. 11 and Eq. 18) converts the pressure-volume product of the gas inside the barrier to the pressure inside the barrier by dividing by the volume inside the barrier. These sets of variable equations represent the mass balance of the carrier gas within the containment system.

The following variables represent the mass balance of the radioactive aerosol particles with the containment system. The variables $A D a_{z}-A D j_{z}$ of the finite element matrix (e.g., Eq. 12 and Eq. 19) are the densities of radioactive aerosol particles within and leaking out of the barrier in grams per square centimeter. They are equal to the mass of radioactive aerosol particles inside the barrier divided by the volume inside the barrier. The variables $d e l R M a_{z}-\operatorname{del} R M j_{z}$ of the finite element matrix (e.g., Eq. 13 and Eq. 20) are the masses of radioactive aerosol particles, in grams, that stay within the barrier in the finite time element. They are equal to the difference between the mass of radioactive aerosol particles leaking in from the next inner barrier minus the mass of radioactive particles leaking into the next outer barrier. The variables $s u m R M a_{z}-s u m R M j_{z}$ of the finite element matrix (e.g., Eq. 14 and Eq. 21) are the masses of radioactive aerosol particles, in grams, that has accumulated with the barrier in all preceding finite time elements. The variable sumRMamb $b_{z}$ of the finite element matrix (see Eq. 22) is not part of the mass balance but is added to calculate the mass of radioactive material that escapes from the outermost barrier.

The constants are the volume inside the barrier, $V_{a}$ for source barrier and $V_{b}$ for other barriers, the finite time interval, delt, and the ratio of Specific Activity to $A_{2}, A_{2}$ mass (i.e., \# $A_{2} / g r a m$ ). $V_{a}$ is determined as follows.

$$
V_{a}=V_{\mathrm{PCV}}+V_{\mathrm{SCV}}+V_{\text {Shield }}
$$

where:

$V_{P C V}$ is the free volume inside the PCV $\left[3389 \mathrm{~cm}^{3}\right.$ from Appendix 4.1 of SAR], $V_{S C V}$ is the free volume inside the SCV $\left[2741 \mathrm{~cm}^{3}\right.$ as calculated below], and $V_{\text {shield }}$ is the free volume inside the shield [11400. $\mathrm{cm}^{3}$ as calculated below].

The volume between the PCV and the SCV was determined by subtracting the free volume within the PCV from the free volume within the SCV as found on Lines 8 and 10, respectively, in Table 3.20 of the SAR. This volume is $2778 \mathrm{~cm}^{3}$. The air volume inside the lead shield by conservatively modeling the SCV as a series of right circular cylinders and subtracting the 
obtained external volume from the calculated internal volume of space within the shield region. The resulting volume is $11,400 \mathrm{~cm}^{3}$. Substituting these values into Eq. 24 yields a value of $1.75 \times 10^{4} \mathrm{~cm}^{3}$ for $V_{a}$.

The volume inside the other barriers, $V_{b}$, is assumed such that the total air volume in barriers outside the source barrier is equal to the arbitrary constant of $4,500 \mathrm{~cm}^{3}$.

The finite time element is assumed to be 10,000 seconds, and the model was evaluated at 30,240 time steps or 3,500 days. The length of time considered was chosen to ensure proper model behavior for long times.

The constant $A_{2}$ mass was calculated as follows.

\section{Case 1}

$$
A_{2} \text { mass }=\frac{\left(\frac{\text { Ci in oxide }}{\text { Grams in oxide }}\right)}{\mathrm{A}_{2}}=\frac{\left(\frac{2.59}{7.48}\right)}{5.41 \times 10^{-3}}=64.0 \mathrm{~A} / \mathrm{gram}
$$

Case 2

$$
A_{2} \text { mass }=\frac{\left(\frac{\text { Ci in oxide }}{\text { Grams in oxide }}\right)}{\mathrm{A}_{2}}=\frac{\left(\frac{16.3}{7.47}\right)}{5.38 \times 10^{-2}}=40.6 \mathrm{~A} / \mathrm{gram}
$$

In the previous equations for $A_{2}$ mass, the values for $A_{2}$ and for curies and grams in oxide can be found in Table 3.3 and Table 3.5, respectively, for Case 1, and in Table 3.4 and Table 3.6, respectively, for Case 2 .

\subsection{Initial Values}

The initial values for the majority of the variables in the finite element matrix are selected to be very small but to avoid element values of zero or less so that the results can be displayed on logarithmic plots. The exceptions are as follows.

The variable $L a_{o}$ (Eq. 16 and Eq. 20 ) is set equal to the leakage rate of the barriers as measured by a leak test conducted with pressure drop of $1 \mathrm{~atm}$ as prescribed in ANSI N14.5. This value is assumed equal to $1 \times 10^{-3} \mathrm{~cm}^{3} / \mathrm{s}$. The variables $N R T a_{o}-N R T j_{o}$ (e.g., Eq. $10-$ Eq. 11 and Eq. $17-$ Eq. 18) are set equal to the product of the volume of the given barrier and its internal pressure. The initial pressure of the source barrier, $P a_{o}$, is set equal to $1.6 \mathrm{~atm}^{5}$, while $P b_{o}-P j_{o}$, are set equal to atmospheric pressure incremented by $0.001 \mathrm{~atm}$ from the outside barrier inward. It is noted that the initial pressure is conservative in that a full puncture of the 9975 through the food can would have relieved this pressure prior to transportation. The variables delNRTa $a_{o}-\operatorname{delNRTj_{o}}$ (e.g., Eq. 10 and Eq. 17) are set equal to the pressure-volume product divided by 10 times the finite time element. Finally, the variable $A D a_{o}$ (Eq. 20) is set equal the mass of radioactive aerosol particles, calculated in Table 3.5 for Case 1 and Table 3.6 for Case 2, times the adherence factor, 0.15 divided by the volume of the source barrier, $V_{a}$, calculated in Section 4.3 by Eq. 24 . The resulting value for $A D a_{o}$ is $6.40 \times 10^{-5} \mathrm{grams} / \mathrm{cm}^{3}$ for both Case $I$ and Case 2.

\footnotetext{
${ }^{5}$ Private communication with Steve Hensel, SRTC.
} 


\subsection{Results and Discussion}

Figures 4.1 display the modeling results for calculations performed to determine the limiting composition case. The figures indicate that the composition used in Case 1 bounds that used in Case 2. This is consistent with the calculations of Section 3.0. As a result, remaining modeling is limited to Case $I$ compositions. Included in the figures are results in which the volume of each barrier, outside the source barrier, has been doubled. Comparing the results for Case 1 with the results of Case 1 with larger barrier volumes indicates that the container volumes used in the model are maximum volumes. This allows greater flexibility in selecting or designing the individual barriers of the multiple barrier system. In order to evaluate the effect of finite time element size, Case 1 was modeled with significantly shorter finite time elements size $(100 \mathrm{sec}$ versus $10,000 \mathrm{sec}$, with the results included in Figures 4.1. These results indicate very little sensitivity to the size of the finite time element.

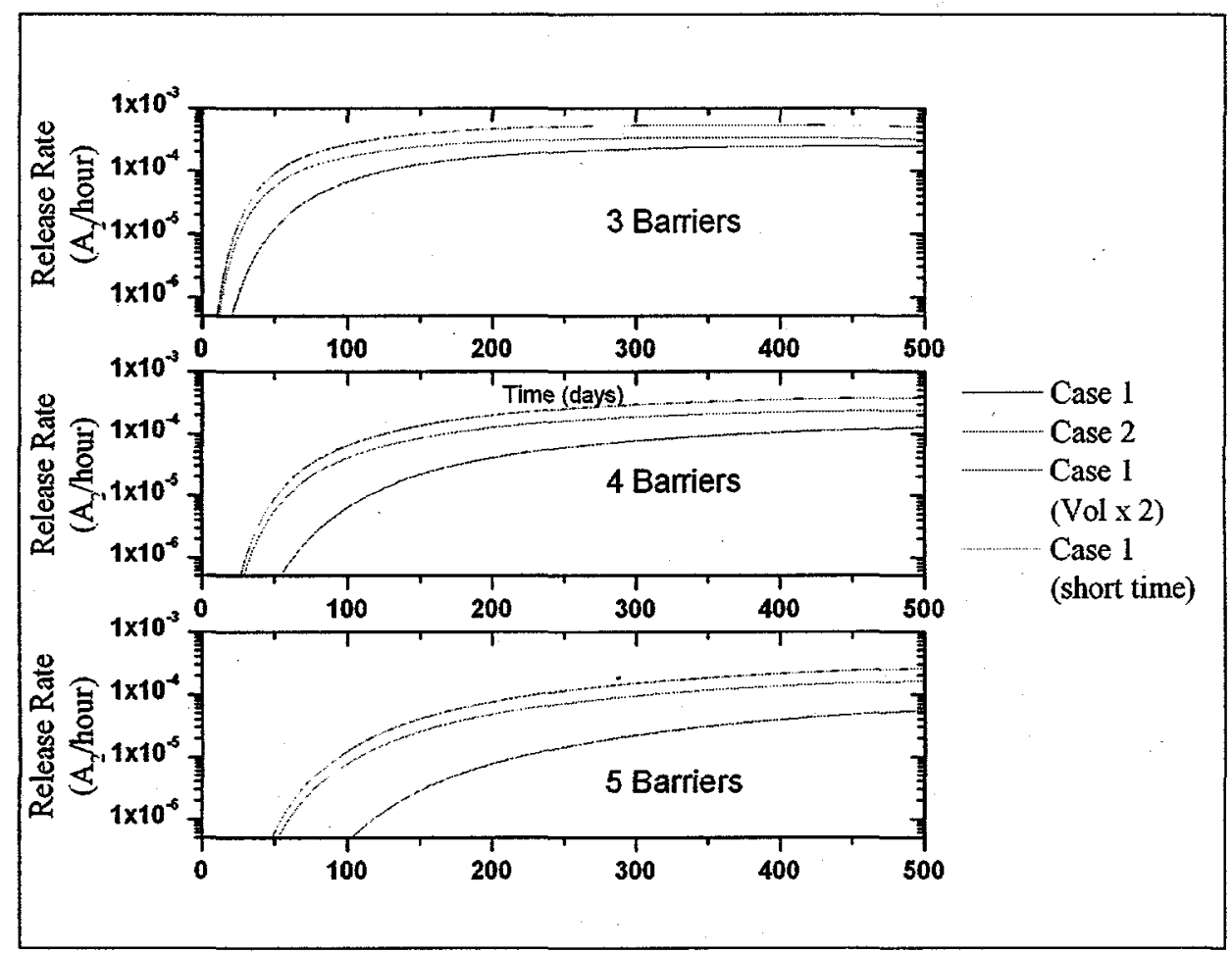

Figures 4.1 Modeling results comparing Case 1, Case 2, Case 1 with double barrier volume, and Case 1 with short time steps.

Figures 4.2 display the behavior of several model parameters. These data are for four leaky barriers. The carrier gas leak rate of the source barrier drops off rapidly as the pressure drop across its boundary decreases. The leak rates of the individual boundaries expectedly reach equilibrium quickly and continue to decrease congruently as the pressure of the entire system is reduced toward atmospheric pressure. The density of radioactive particles within the containment system becomes uniform within a couple years. This is further illustrated in the final plot of these figures. This plot displays equal amounts of radioactive particles in the barriers surrounding the source barrier. They are equal because their volumes and particle densities are equal. The rate at which the masses of radioactive particles in the source barrier and in ambient air change continually decrease as the pressure of the source barrier approaches unity. 


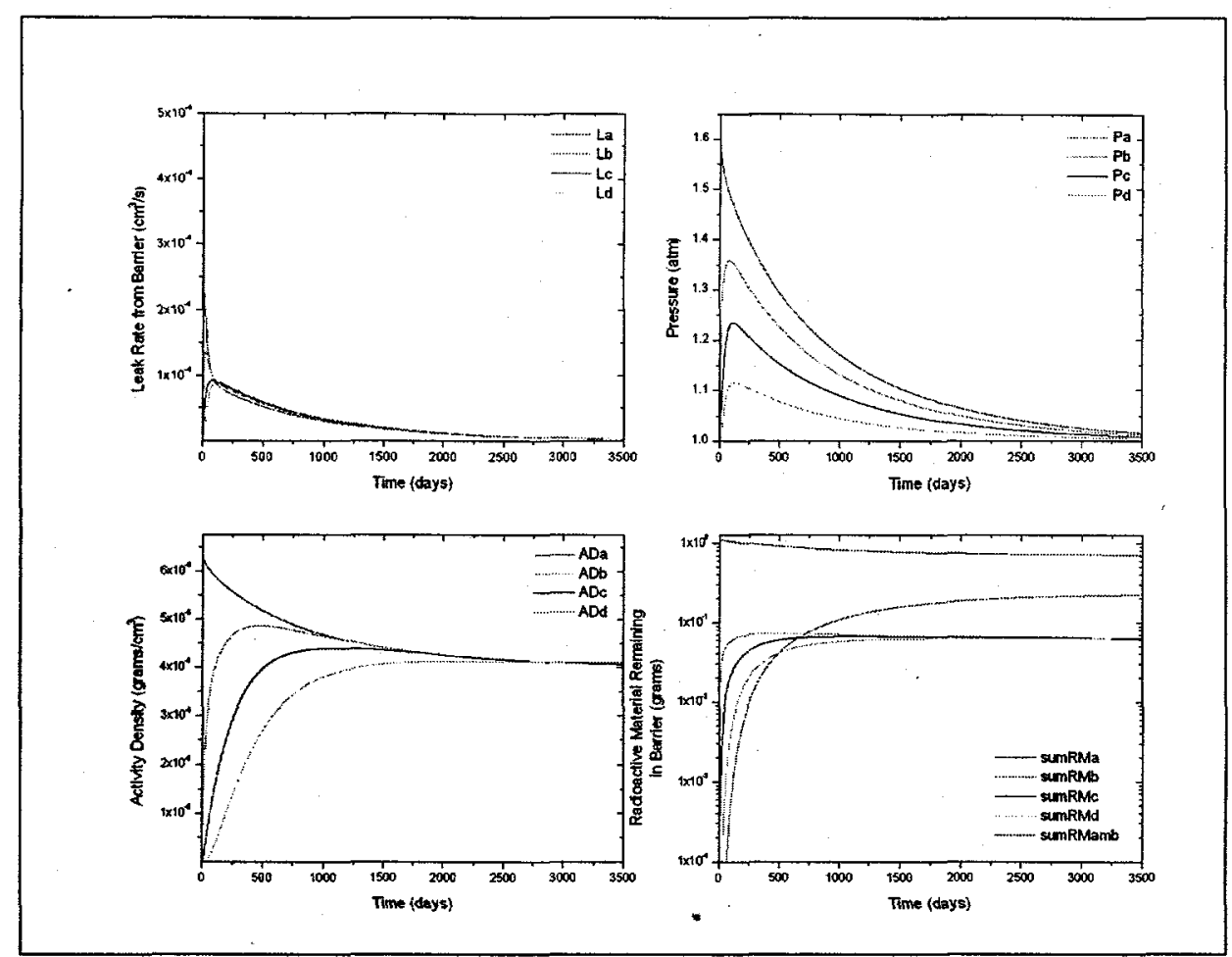

Figures 4.2 Carrier gas leak rates; Pressure inside boundary; Density of radioactive particles; and Radioactive particle accumulation inside boundary.

The release rates of radioactive material from the individual barriers of a four leaky barrier system are shown in Figures 4.3. As with the carrier gas leak rates, shown above, the radioactive material release rates quickly approach equilibrium and continue to decrease with time as the density of radioactive material available for transport and pressure drop across barriers decrease. The figures demonstrate that there is always a driving force for release, demonstrated by a positive release rate at times greater than zero. However, reduction in model conservatism allows credit for the reduction in overall release as the driving force for release, relative pressure, is reduced. The model does not consider diffusive releases that are overwhelmed by the convective releases modeled here for the time of interest for this analysis.

Figures 4.4 display the radioactive material release rates for multiple leaky barrier systems. Systems of two to ten leaky barriers are considered in this analysis and are shown the the figures. The figures present data on the release of radioactive material from the outer barrier of the containment system. The regulations require a release rate of less than $10^{-6} \mathrm{~A}_{2} /$ hour for a shipment of radioactive material. Figures 4.4 shows that achieving this release rate is possible through the implementation of as few as three leaky barriers. This condition exists for about ten days, after which time, the release rate exceeds the release limit. Additional barriers will allow for significant increases in the time prior to exceeding the limit. 


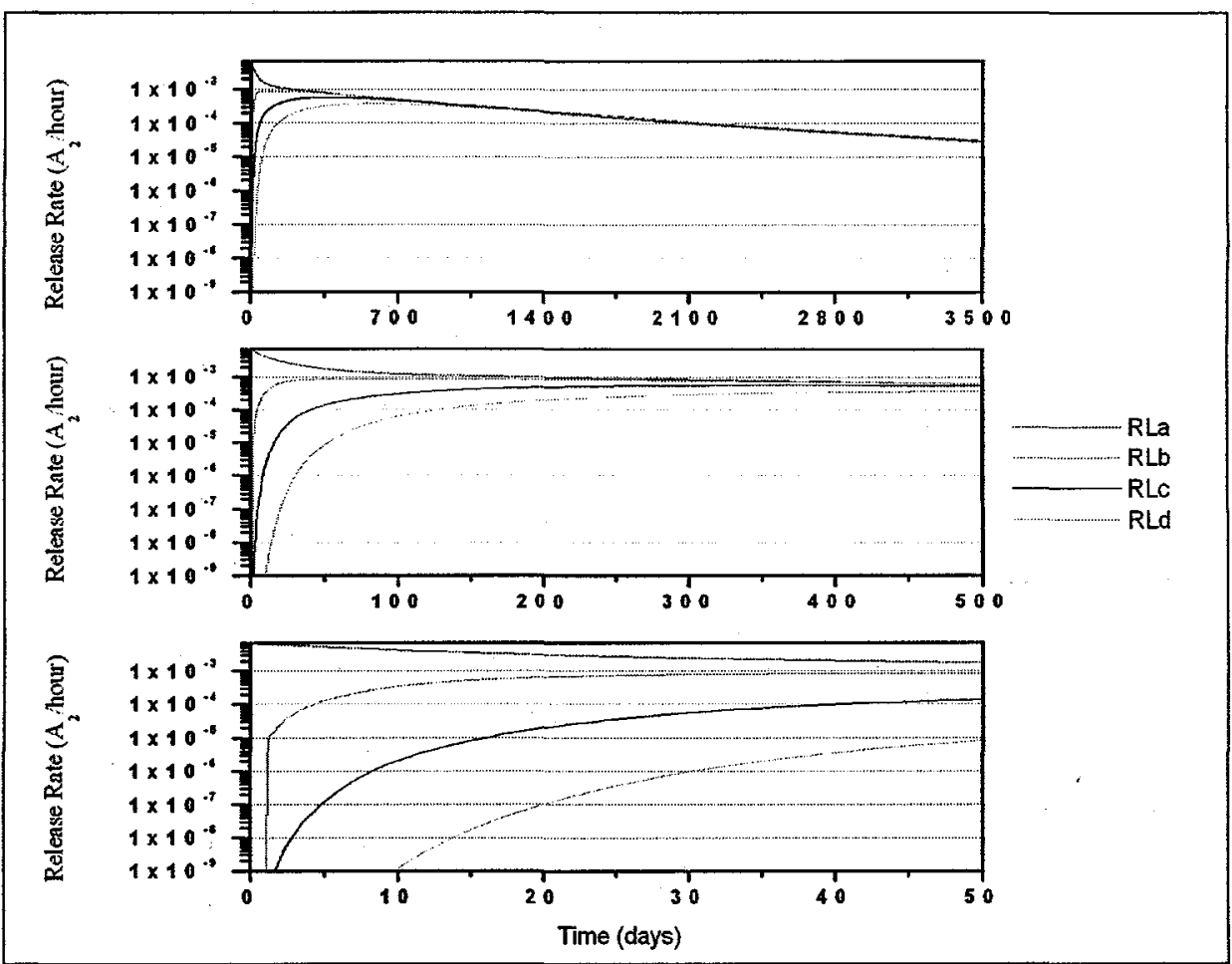

Figures 4.3 Radioactive material release rate for individual barriers.

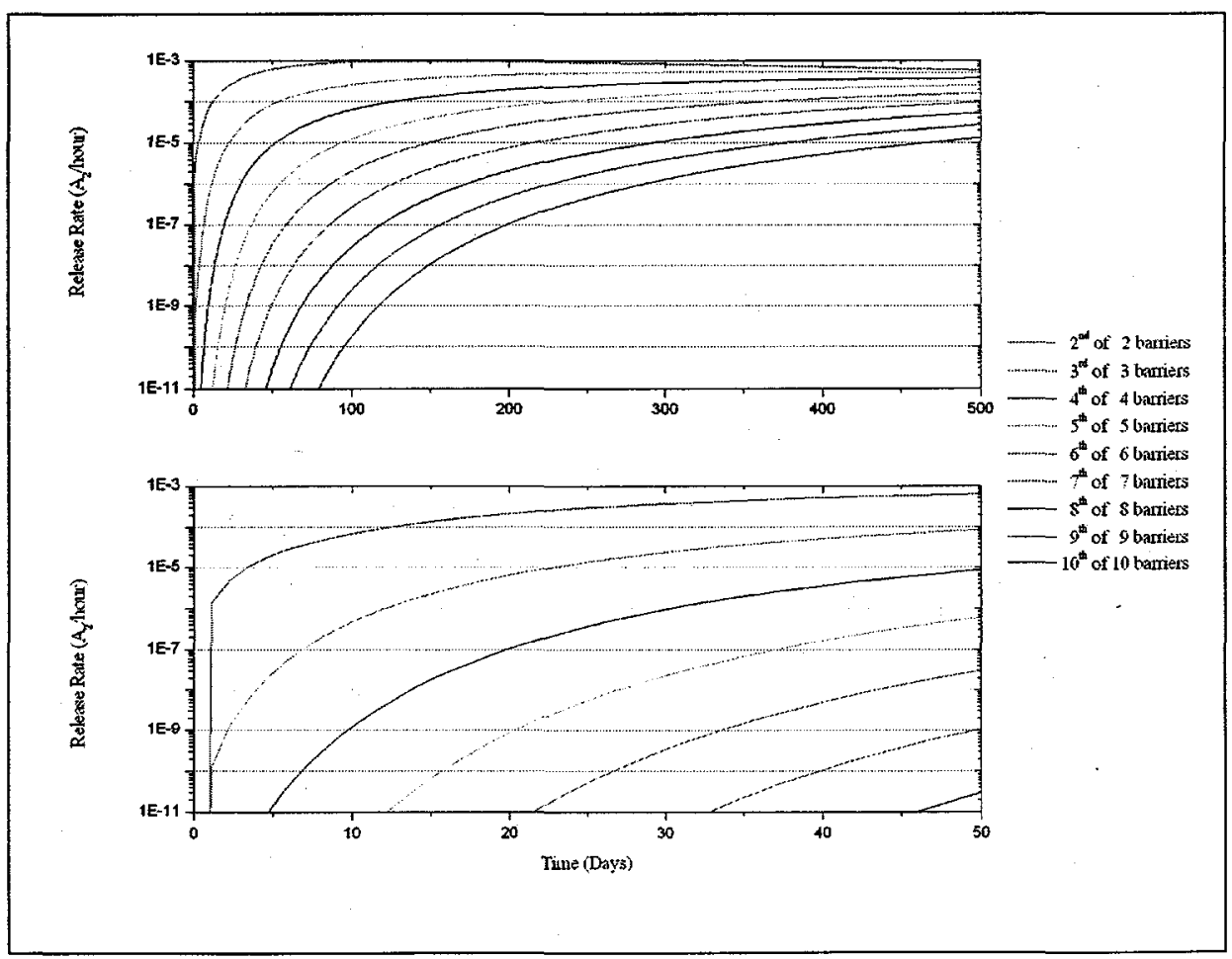

Figures 4.4 Radioactive material release rate for multiple leaky barrier systems. 


\subsection{CONCLUSIONS}

Results of the containment evaluation of the 9975 package with plutonium metal contents indicate the necessity that a conventional containment system be leak-tight. In lieu of such a system, an alternative containment system has been evaluated. This system contains several redundant barriers that are individually unable to comply with the current transportation requirements. This report represents the theoretical basis for using such a containment system. The analysis provides a conservative estimation of the release rate of radionuclides from several multiple leaky barrier systems. However, it would be useful to benchmark the results of this analysis through an experimental program.

The analysis of multiple leaky barrier systems indicate that as few as three barriers with leak rates of less $1 \times 10^{-3} \mathrm{~cm}^{3} / \mathrm{sec}$ can be used successfully to maintain a containment system release rate less than $1 \times 10^{-6} A_{2} /$ hour. The container volumes used in this analysis are nominal, less than 4,500 $\mathrm{cm}^{3}$, and increasing container volume results in longer times prior to exceeding the release limit of $10^{-6} A_{2} /$ hour. 
WESTINGHOUSE SAVANNAH RIVER CO. REPORT WSRC-TR-99-00476

DISTRIBUTION

\section{SAVANNAH RIVER SITE}

R. J. Skwarek, 704-C

M. W. Barlow, 704-C

D. H. Poss, 707-C

W. B. Epling, Jr., 705-K

C. R. Wolfe, 773-A

M. A. Ebra, 773-42A

S. M. King, 773-54A

E. K. Opperman, 773-42A

R. J. Gromada, 773-53A

P. S. Blanton, 773-54A

N. C. Iyer, 773-A

R. L. Sindelar, 773-41A

G. T. Chandler, 773-A

D. W. Vinson, 773-41A 